\title{
Integrating gender medicine into the workplace health and safety policy in the scientific research institutions: a mandatory task
}

\author{
Anna Maria Giammarioli ${ }^{(a)}$, Alessandra Siracusano ${ }^{(b)}$, Eugenio Sorrentino $^{(\mathrm{c})}$, \\ Monica Bettoni $^{(\mathrm{d})}$ and Walter Malorni ${ }^{(\mathrm{a})}$ \\ (a) Dipartimento del Farmaco; ${ }^{(b)}$ Malattie Infettive, Parassitarie ed Immunomediate; \\ (c) Unità di Gestione Tecnica, Patrimonio Immobiliare e Tutela della Salute dei Lavoratori; \\ ${ }^{(d)}$ Direzione Generale, Istituto Superiore di Sanità, Rome, Italy
}

\begin{abstract}
Background. Gender medicine is a multi-faceted field of investigation integrating various aspects of psycho-social and biological sciences but it mainly deals with the impact of the gender on human physiology, pathophysiology, and clinical features of diseases. In Italy, the Decree Law 81/2008 recently introduced the gender issue in the risk assessment at the workplaces. Aims. This review briefly describes our current knowledge on gender medicine and on the Italian legislation in risk management. Conclusions. Public or private scientific institutions should be the first to pay attention to the safety of their workers, who are simultaneously subjected to biological, chemical and physical agents. Main tasks of risk management in scientific research institutions are here analyzed and discussed in a gender perspective.

Key words: gender medicine, risk management, occupational exposures, communicable diseases, non communicable diseases, Italian law, scientific institutions.

Riassunto (Integrare la medicina di genere nelle politiche di salute e sicurezza negli istituti di ricerca a carattere scientifico: un impegno obbligato). Introduzione. La medicina di genere valuta l'impatto del genere sulla fisiologia umana, sulla fisiopatologia e sulle caratteristiche cliniche delle malattie, integrando aspetti biologici, sociologici, etnici e culturali. Il decreto legge 81/2008 ha introdotto il genere nella valutazione dei rischi sul luogo di lavoro, tuttavia non esiste ancora una normativa genere-specifica riguardante il personale delle istituzioni scientifiche, che è soggetto, in uno stesso tempo ad agenti biologici, fisici e chimici, oltre che a problemi psicosociali come tutti gli altri. Scopi. In questa rassegna vengono discussi alcuni aspetti della medicina di genere in relazione alla normativa italiana e alla valutazione del rischio. Conclusioni. È infatti indispensabile che gli istituti scientifici pubblici e privati adottino strategie di prevenzione che tengano conto del genere per assicurare uguale tutela a uomini e donne.
\end{abstract}

Parole chiave: medicina di genere, malattie trasmissibili, malattie non trasmissibili, tutela dei lavoratori, valutazione del rischio, legge italiana.

\section{GENDER MEDICINE:}

\section{A NOVEL ISSUE IN BIOMEDICINE}

Since 1998, the World Health Organization (WHO) has issued a "gender challenge" to nations and international organizations. It was a call for: i) a better appreciation of risk factors involving women's health; ii) the development of preventive strategies to lessen the impact of diseases that disproportionately plague older women (e.g., coronary heart disease, osteoporosis, and dementia); iii) an increased emphasis on understanding why men die sooner than women [1]. Stemming from this statement, a new field of scientific investigation was born: the so-called gender medicine (GM). In fact, in the last years a large number of studies (more than 2000 scientific articles in the year 2010) evaluated the differences between men and women in both health and disease.
First of all it has to be underlined that the meaning of terms "sex" and "gender" are different. While "sex" is a characteristic grounded in physiological and biological differences, "gender" is a characteristic of social and cultural roles of the two sexes and it reproduces the existing ideas about the mission of each sex in the society. The concept of gender refers to a complex interrelation and integration of sex - as a biological and functional marker of the human body - and psychological and cultural behaviour (due to ethnical, social, and religious background). Gender is an essential determinant of social outcomes, including health. In particular, GM focuses on the impact of the gender on human physiology, pathophysiology, and clinical features of diseases. It is a multi-faceted science integrating aspects of biology, sociology, ethnicity and culture. 


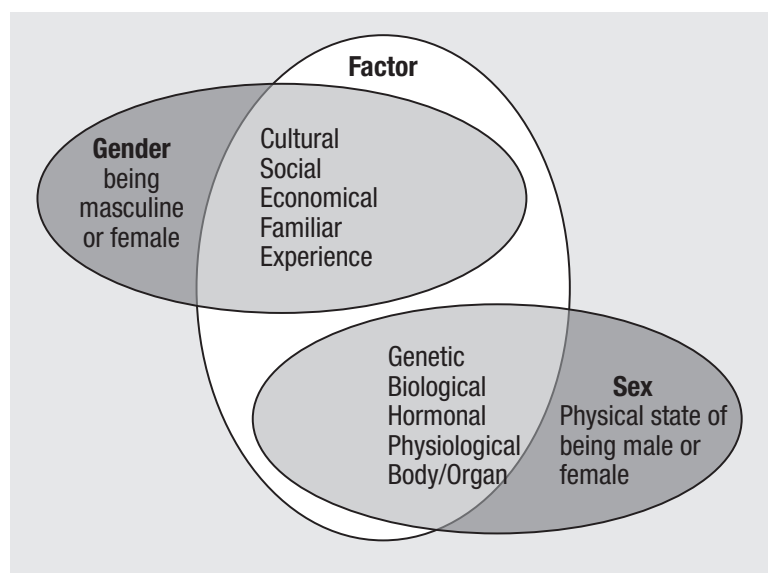

Fig. $\mathbf{1}$ | Factors influencing gender and sex differences in human health.

The concepts related to the terms sex and gender are still a matter of debate. The term "sex" is however referred as to the biological features of human beings whereas the term "gender" takes into account other identifiers such as the ethnicity, the cultural issue and the socio-economic class [2].

GM focuses on the recognition of the differences and similarities between men and women from a health point of view. GM thus involves the prevention, diagnosis, pathogenesis and outcome of diseases, as well as the efficacy and safety of treatments $[3,4]$. This reflects on biomedical studies: both experimental and clinical investigations should consider gender as a key variable and should provide answers to the plethora of questions raised by the discovery of a wide and relevant gender disparity in human health and disease. However, the investigation design and analysis should also consider, at least in some instances, the social relationships (Figure 1): the phenotype inevitably depends on the interaction of the individual with the environment $[5,6]$. It means that scientific studies must analyze the complex ways in which biological and social factors interact with the individual, carefully considering the different experiences, behaviours, social norms and status of men and women that underpin health status, health-seeking behaviour and access to resources. Prevention, treatment, rehabilitation and the delivery of care need to be adapted and to consider all these factors that can influence the health of both women and men.

Hence, GM encompasses several fields of investigation: from the pathogenesis of diseases to their diagnosis, treatment and clinical management. However, several critical points should be considered and faced. Among these, the evidence that few women are usually enrolled in clinical trials and that gender-specific analyses are barely included in the evaluation of the results obtained [7]. A further key example of the pitfalls in the growth of the field of GM is represented by pharmacological studies. It has been demonstrated that gender affects drug response [4]. Gender differences have been described in pharmacodynamics and pharmacokinetics but, strikingly, their role in clinical practice still remains unexplored. Women and men display differences in distribution, metabolism, and excretion of drugs. Sex hormones, e.g. estrogens, also play a relevant role. Increased knowledge on drug response in a gender perspective will be certainly a milestone of future trends in pharmacology [8].

Below, in Box 1, a list of useful gender related links.
Box 1
Some gender-related links
http://www.isogem.com
http://www.gendermed.org
http://www.gendermedicine.org
http://gender.stanford.edu
http://www.lorenzinifoundation.org
http://www.who.int/gender/en

\section{EXAMPLES OF GENDER-ASSOCIATED DISEASES}

Besides pathologies associated with reproductive organs gender differences have been detected in the incidence, morbidity, progression and outcome of distinct diseases. In Table 1 some diseases showing a gender disparity have been reported. In the following paragraphs three paradigmatic examples of diseases with gender disparity will be briefly described.

\section{Gender and cardiovascular disease}

Cardiovascular disease (CVD) is the major cause of death in industrialized countries. Several epidemiological studies (the Framingham in particular) have investigated into the evolution of cardiovascular disease hypothesizing the presence of a gender disparity in the pathogenetic and progression deter-

Table 1 | Gender disparity in some human pathologies

\begin{tabular}{ll} 
Pathology & Gender disparity \\
\hline $\begin{array}{l}\text { Cardiovascular disease } \\
\text { Some forms of cancer }\end{array}$ & $\begin{array}{l}\text { Delayed in women } \\
\text { Differences in incidence, } \\
\text { prognosis and response to therapy } \\
\text { Disability (bedridden) }\end{array}$ \\
$\begin{array}{l}\text { Other disabilities (sight, motion, incidence in women } \\
\text { hearing, speech) }\end{array}$ & Higher incidence in women \\
Rates of chronic disease & Higher incidence in women \\
Osteoarthritis/Arthritis & Higher incidence in women \\
Osteoporosis & Higher incidence in women \\
Hypertension & Higher incidence in men \\
Diabetes & Higher incidence in women \\
Depression and anxiety & Higher incidence in women \\
Senile dementia-Alzheimer's & Higher incidence in women \\
Autoimmune diseases & Higher incidence in women
\end{tabular}


minants detectable in men and women [10]. For instance, women were found to outlive men and to experience fewer atherosclerotic cardiovascular events [10]. This gap in incidence closes with advancing age, when CVD becomes the leading cause of death in women as well as in men [11, 12]. Women develop CVD when they are about 10 years older than men and typically after the menopause. Ovarian hormones, present during premenopausal period, protect women from the risk of CVD respect to agematched men [13]. This suggests that hormones may be important in reducing the risk of vascular disease in women. Estrogens seem to be able to protect the vascular system by enhancing endothelial function and vasodilation, by inhibiting vascular smooth muscle (VSM) cell proliferation, and by improving HDL and LDL cholesterol levels [14, 15]. However, identification of appropriate gender-associated risk factors appears as crucial in determining cardiovascular events in the two sexes $[16,17]$. In men, cholesterol is more important than in women, in whom arterial hypertension, diabetes and their combination has a greater role in determining cardiovascular risk. Marked gender differences also exist in the manifestations of atherosclerosis and in the pattern of symptoms in the two sexes. Angina, the most common manifestation of coronary heart disease, is frequently uncomplicated in women, whereas in men it tends to evolve to an acute coronary syndrome [18]. The clinical manifestation of acute ischemic syndromes is also different in men and women and, because of the frequent atypical symptoms, women tend to underestimate the importance of them. Furthermore, preventive therapies are less often recommended to women than to men, although hormone replacement therapy still represents a concrete strategy in the prevention of cardiovascular diseases in women $[14,15]$. Particularly important is the control of lipids and other factors as central obesity and impaired glucose regulation that, contributing to the metabolic syndrome, atherosclerotic disease, and type 2 diabetes, are known to increase the risk of coronary and cardiovascular mortality [19, 20].

\section{Gender and cancer}

After CVDs, tumors are the leading cause of death [21]. A gender disparity was described for several forms of cancer [22]. Cancer is a multifactorial disease that develops through the accumulation of damage and external (exposure to carcinogens, life style like smoking or diet, radiation and infectious organisms) and internal (inherited mutations, hormones, immune system disorders). Gender differences in incidence and mortality were found not only in typically male or female tumors associated with reproductive organs, but also in those which, in theory, should not be linked to the gender issue.

Since environmental and occupational exposures can contribute to various stages in the initiation or progression of a tumor, the risk assessment should account for gender and life cycle differences. Women may be more susceptible to certain toxic factors (for the same exposure). This is seemingly due to differences in the enzymatic ability to metabolize or eliminate potential carcinogens. Furthermore, biological characteristics of women (a lower average weight, a higher percentage of fat, a lower plasma volume etc.) can affect the pharmacokinetics of drugs and toxic agents. Last but not least, gender differences in the metabolism and pharmacokinetic of chemicals could display a significant gender disparity in the response to chemotherapy [23-25]. In Table 2 some examples of cancers showing a gender disparity is provided.

\section{RADIATION, CANCER AND GENDER}

Among environmental risks, radiation appears as paradigmatic. Radiation and radioactive materials are in fact part of our environment and everyone is exposed to background radiation daily. In addition, radiation and radioactive materials are produced by many human activities. Radiation is a common and valuable tool in medicine, research and industry. It is used in medicine to diagnose illnesses, and in high doses, to treat diseases such as cancer. The use of radioactive substances is still widespread in scientific research although the use of alternative tests, if available, are trying to limit their use.

There are some difficulties and limitations on obtaining significant information on the health effects of exposure to radiation. Radiation protection is based on risk factors extrapolated from existing substantial information from epidemiological studies on the health effects of high and acute dose exposure of man to radiation, including studies of atomic bomb survivors and of low dose exposure of individuals irradiated medically or occupationally. The principal adverse biological effects associated with ionizing radiation exposures from radioactive substances in the environment are carcinogenicity, mutagenicity, and teratogenicity [26].

Studies of humans exposed to internal or external sources of ionizing radiation have shown that the incidence of cancer increases with increased radiation exposure. The adverse effects of exposure to radiation are due to the energy deposited in sensitive tissue, which is referred to as the radiation dose. Different tissues and organs show varying degrees of sensitivity.

There are a number of factors that influence the individual's sensitivity to radiation. These include genetic factors, age but gender has also been hypothesized to play a role. In fact, females have a considerably higher risk of cancer compared to males exposed to the same levels of radiation [27]. Breast cancer risk among women exposed to radiation is greatest among women who were exposed before age 20 , and least when exposure occurred after menopause [28]. The thyroid gland also represents a potential target organ for radiation-related damage and thyroid carcinoma is a possible high-dose effect of occupational exposure to ionizing radiation. Gender bias in the incidence of thyroid cancer, is well known. In fact thyroid cancer is the seventh most common malignancy 


\begin{tabular}{|c|c|c|c|c|}
\hline Cancer & $\begin{array}{c}\text { Men } \\
\text { Incidence (\%) } \\
5.3 \text { million cases }\end{array}$ & $\begin{array}{c}\text { Men } \\
\text { Mortality (\%) } \\
4.7 \text { million deaths }\end{array}$ & $\begin{array}{c}\text { Women } \\
\text { Incidence (\%) } \\
4.7 \text { millions cases }\end{array}$ & $\begin{array}{c}\text { Women } \\
\text { Mortality (\%) } \\
2.7 \text { million deaths }\end{array}$ \\
\hline Prostate & 10.2 & 4.3 & - & - \\
\hline Breast & - & - & 57 & 13 \\
\hline Lung & 18 & 17 & 7 & 10 \\
\hline Colon/Rectum & 9.4 & 5.4 & 9.4 & 8.7 \\
\hline Stomach & 10.5 & 8.6 & 6.7 & 8.9 \\
\hline Liver & 7.5 & 7.3 & 3.5 & 6.0 \\
\hline Cervix uteri & - & - & 10.0 & 8.6 \\
\hline Oesophagus & 5.3 & 4.8 & 2.8 & 4.1 \\
\hline Bladder & 4.9 & 2.1 & 1.6 & 1.2 \\
\hline Non-Hodgkin lymphoma & 2.9 & 1.9 & 2.5 & 2.5 \\
\hline Leukemia & 2.7 & 2.3 & 2.4 & 3.2 \\
\hline Oral Cavity & 3.2 & 1.7 & 2.0 & 1.7 \\
\hline Pancreas & 2.2 & 2.3 & 2.1 & 3.7 \\
\hline Kidney & 2.2 & 1.2 & 1.5 & 1.2 \\
\hline Ovary & - & - & 4.0 & 4.2 \\
\hline Melanoma & 4.0 & 2.8 & 3.0 & 1.9 \\
\hline
\end{tabular}

in women, but it is not among the most common 15 cancers in men [29]. Although little is known about association of ionizing radiation with autoimmune thyroid disease (AITD), it is known that females with occupational exposure to ionizing radiation had more AITD than equally exposed males [30].

\section{GENDER AND WORKPLACE STRESS}

The deep changes which have taken place in the work environments have led to considerable changes in organizations introducing new occupational risks as the risks from job-related stress. Workplace stress is the harmful physical and emotional response that occurs when there is a poor match between job demands and the capabilities, resources, or needs of the worker [31]. Men and women report different reactions to stress, both physically and psychologically. In particular, several epidemiological studies describe a higher incidence of anxiety and depressive disorders in women than in men $[31,32]$. Men and women attempt to manage stress in very different ways and perceive their ability to do so - and the things that stand in their way - in markedly different ways. Women are more likely to report physical symptoms associated with stress, they are better in establishing relationships with others in their lives and, in some occasions, these connections are important to their stress management strategies (http://www.apa.org). The job-related stress is caused by various factors in the working environment and is also associated with various biological reactions that may ultimately lead to compromised health, such as cardiovascular disease, or in extreme cases death. Stress-related disorders encompass a broad array of conditions, including psychological disorders (e.g., depression, anxiety, post-traumatic stress disorder) and other types of emotional strain (e.g., dissatisfaction, fatigue, tension, etc.), maladaptive behaviors (e.g., aggression, substance abuse), and cognitive impairment (e.g., concentration and memory problems). In turn, these conditions may lead to poor work performance or even injury [32].

\section{GENDER, HEALTH AND THE CURRENT ITALIAN LEGISLATION}

Gender equality is a milestone of Italian legislation. In the Italian Constitution, the principles of gender equality (art. 3) and equal pay (art. 37) are upheld. This principle should be reflected in the priorities of State policies and of the laws that are being drafted in the country.

The European Agency for Safety and Health at Work defines a "gender-sensitive legislation" as regulations that clearly recognize gender issues and are aimed at: a) creating a positive environment, through economic and social policies, for the full development of women to enable them to realize their full potential; b) ensuring the enjoyment of all human rights and fundamental freedom by women on an equal basis with men in all spheres political, economic, social, cultural, as well as civil; c) ensuring equal access to participation and decision-making of women in social, political and economic life; d) ensuring equal access by women to health care, quality education at all levels, career and vocational guidance, employment, equal remuneration, occupational health and safety, social security; e) strengthening legal systems aimed 
at the elimination of all forms of discrimination and violence against women; f) changing societal attitudes and community practices by active participation and involvement of both men and women; g) fostering a gender perspective in all political processes; g) building and strengthening partnerships with civil society, particularly women's organizations.

In Italy, there are some laws that establish some principles and fundamental rights. The law on equality (No. 903/77); the law on affirmative action (No. 125/91); the law on maternity (No. 1204/71); the law on female entrepreneurship (No. 215/92); the parental leave act (No. 53/2000). The European Directive (2006/54/CE) which was transposed into Italian law through a legislative Decree on 3 December 2009 makes changes to two already existing laws: the Code regarding equal opportunities (Decree Law No. 198/2006) and the Consolidated act on the protection and support of maternity and paternity (Decree Law No. 151/2001). The European Commission had formally warned the Italian government that it was required to transpose the recast Directive 2006/54/EC on the implementation of the principle of equal opportunities and equal treatment of men and women in matters of employment and occupation. The Italian Decree introduces important innovations regarding equal opportunities committees, discrimination and sanctions. It gathers all gender anti-discriminatory provisions and regards women's participation in all fields, including the working relationship (Table 3). An innovative aspect, in this regard, is the recent institution (Law No. 183/2010, art. 21) of the Comitato Unico di Garanzia (CUG) that substitutes, in all the public workplaces, the previous Committee for equal opportunities (1984/630/CE), also including the Committee against mobbing. This Committee (CUG), as required by the EU and national legislation, promotes the culture and the effective enforcement of the equal opportunity principle. It promotes the substantial equality in employment through measures aimed at removing implicit and explicit forms of discrimination and exploitation of the capacity of all staff.

Table 3 | Main Italian anti-discrimination laws

\section{Anti-discrimination Laws \\ Law No. 903/1977 \\ Equal treatment of women and men at work \\ Law No. 125/1991 \\ Law-making activeness for the realization of gender equality in the work}

Legislative Decree No. 151/2001

Consolidated act on the protection and support of maternity and paternity

\section{Legislative Decree No. 216/2003}

Implementation of Directive 2000/78/EC for equal treatment of men and women in matter of employment and occupation

\section{Legislative Decree No. 198/2006 \\ Code of Equal Opportunities between men and Women}

\section{Legislative Decree No. 5/2010}

Implementation of Directive 2006/54/CE of the principle of equal opportunities and equal treatment of men and women in matters of employment and occupation

\section{Law No. 183/2010}

Provisions concerning public employment and labor disputes

\section{Aim}

To prohibit discrimination based on sex in access to employment, regardless of the mode of application and any sector or branch of activity, at all levels of the occupational hierarchy

To favor the employment of women and realize the equality between men and women at work, in order to remove obstacles that impede the realization of equal opportunities

To regulate the leave, breaks, permits and the protection of women workers and workers associated with maternity and paternity of illegitimate children, adoptive and foster care, and economic support to maternity and paternity

To put in place a general framework to ensure equal treatment of individuals in the European Union, regardless of their religion or belief, disability, age or sexual orientation, as regards access to employment or occupation and membership of certain organizations

To eliminate any distinction, exclusion or restriction based on sex which has the effect or purpose of impairing or preventing the recognition, enjoyment or exercise of human rights and fundamental freedoms in the political, economic, social, cultural and civil or any other field

To ensure equal treatment and opportunities for women and men in all field

To delegate the Government in matters of work reorganization of heavy-duty, institutions, etc..., employment of women, as well as measures to combat undeclared work and provisions of public work and labor disputes

\section{The Italian law on the healthy and safety of workers}

Legislative Decree №. 81 of 2008

Code for the health and safety of workers

(Consolidated Act on health and safety

at the workplace)

Legislative Decree No. 106 of 2009

Modifies and integrates Decree No. 81 of 2008
To improve and guarantee a better standard of safety and health protection. To increase the sanctions for employers who fail to adequately assess workers' health and safety risks at workplaces involving high levels of danger and exposure to risks

To simplify certain formal aspects of matters concerning health and safety 


\section{THE SAFETY IN THE WORKPLACE: THE ITALIAN LAW}

Traditionally, occupational safety and health legislation was often discriminatory, banning women from performing certain work and concentrating on risks in male-dominated occupations. In the past, most research about working life had a gender-neutral perspective. The assumption that the working life conditions are the same for women and men is erroneous, and needs to be corrected. Taking a "gender-neutral" approach to risk assessment and prevention can result in risks to female workers being under-estimated or even ignored altogether.

Gender differences in occupational distribution (men and women working in different jobs and therefore being exposed to different risk factors) play an important role in many of these differential outcomes [33]. However, differences in occupational morbidity have also been observed for men and women with the same job title, suggesting that even in the same occupation, men and women are not equally exposed to particular risk factors for disease. Understanding gender differences in occupational exposure, both between and within occupations, is a necessary first step towards understanding gender differences in occupational morbidity. Therefore, it is important to include GM issues in workplace risk assessments and to improve the working conditions of both women and men.

European labor law on health and safety is characterized by its emphasis on the anticipation of risk, rather than on protection against danger once risks have materialized. A crucial factor is the identification and assessment of hazards, with responsibility for the control of these hazards. The Italian Legislative Decree No. 81/2008 (known as "Testo Unico Sicurezza Lavoro") transposes in Italy the European Directive on the protection of safety and health of workers (Table 3). With this Decree Italian legislation introduces a new idea of workplace safety and health, not neutral but systematically marked by gender difference (art. 1) and establishes a system that protects the women during all the working life, not only during pregnancy and maternity. The Decree No. 81/2008 states the object of the risk assessment (art. 28) including all risks for the safety and health of workers, such as stress job-related, pregnancy and gender. This law does not specify methods and procedures by which this obligation can be considered discharged. The employer is required, in particular, to organize a protective and preventive service, which is responsible for identifying risk factors and for their elimination or reduction to a minimum. The Decree No. 81/2008 contains a number of requirements on medical screening (art. 40), establishing the person responsible for the regular assessment and certification of employees' physical fitness to perform the tasks assigned to them. Another of its important provisions concerns the election or appointment of a workforce representative on matters of health and safety who has to gather particular information and consultation rights. In addition, the employer is under an obligation to provide other employees with all general information on the risks present in the workplace and specific information on the risks associated with performance of the tasks assigned to individuals. Lastly, employees must receive adequate health and safety training specific to their own particular job at the time of their recruitment, in the event of a transfer or change of job, and in the event of the introduction of new work equipment or any new technology. There is also provision for special and appropriate training for safety representatives. To note, in the recent legislation numerous aspects related to non-neutrality of health, including for example differences of age and geographical origin, are markedly innovative and point to gender as a focal issue [34].

\section{THE SCIENTIFIC INSTITUTIONS: A PECULIAR WORK ENVIRONMENT}

Some recommendations improve gender sensitivity in healthcare but there is still no specific legislation concerning the staff of scientific institutions, which is a peculiar health-related sector of work activity. The workers of the scientific institutions are subject, at the same time, to biological, physical and chemical agents as well as to psychosocial problems. In particular, the damage caused by biological (e.g., infections), chemical (e.g. carcinogens) and physical (e.g. radiations) risks may cause a plethora of diseases and gender differences should be taken into account in monitoring these peculiar workplaces. In fact, research institutes are often involved in different fields of investigation that can increase the risks for all the people directly or indirectly involved in such researches. Either laboratory staffs or administrative offices personnel can be "embedded" in a sort of unique microenvironment where infectious agents, toxicants, radiations etc are often studied in contiguous rooms or laboratories. Although the efforts to allow research workers safety is taken into careful consideration in these institutes, the peculiar conditions of these workplaces needs an indubitable further attention. In particular, the high prevalence of female workers implies a specific attention at the monitoring of the work risks in a gender perspective. The problem is to understand whether there are tools, practices and appropriate expertise to understand, detect, assess and intervene with respect to these issues. Gender-related risk assessment in these workplaces should be better analyzed: in particular, this evalutation should be performed not only on the basis of the current low rules but, also, on the basis of the idea that these buildings, rooms, facilities, services should provide the maximum safety level organization. However, a professional approach to the analysis and monitoring of risk factors in scientific and research institution is still at the beginning of the due course. We are convinced that the specific role for GM must rapidly be introduced in these peculiar work places. It should be considered in a way 
that could represent a starting point for a reappraisal and a rethinking of all the "castle" of a scientific institution: from the buildings and their structural features to the monitoring of worker risks, but with a gender biased knowledge. The Istituto Superiore di Sanità (ISS) is the leading technical and scientific public body of the Italian National Health Service. Its activities include research, control, training and consultation in the interest of public health protection. Currently, about 1900 staff workers are present in the ISS and more than $56 \%$ are women. Of note, $52 \%$ of them are scientists and $66 \%$ is involved in administrative tasks. The institution recently approached this question including GM and its tasks in a careful and innovative approach to the monitoring of its personnel. The starting point at the ISS is the ongoing information of workers and the training of young scientists about gender disparity and consequent awareness of the state of workplace safety and gender-related risk assessment evaluations. Furthermore, specific analyses and databases are being instructed in order to take into account sex as a crucial determinant for the evaluation of worker wellness, safety and risk assessment.

\section{THE RECOMMENDATIONS OF EU AND BEYOND}

On 15 December 2011, the European Parliament (EP) adopted a resolution on the mid-term review of the European strategy 2007-2012 on health and safety at work (Report 2011/2147(INI)). The text stresses the importance of a European health and safety strategy and sends a clear signal to the European Commission: The Parliament intends to maintain

\section{References}

1. World Health Organization(Ed.). The World health report 1998: Life in the $21^{\text {st }}$ century. A vision for all. Geneva: WHO; 1998.

2. Franconi F. Sex and gender analysis in medical and pharmacological research. United Nations Division for the Advancement of Women (DAW, part of UN Women) United Nations Educational, Scientific and Cultural Organization (UNESCO) EGM/ST/2010/EP.12 September 2010. Expert group meeting gender, science and technology. Paris, France, 28 September - 1 October 2010.

3. Legato MJ. Gender-specific medicine: the view from Salzburg. Gend Med 2004;1(2):61-3

http://dx.doi.org/10.1016/S1550-8579(04)80011-1

4. Franconi F, Brunelleschi S, Steardo L, Cuomo V. Gender differences in drug responses. Pharmacol Res 2007;55(2):81-95. http://dx.doi.org/10.1016/j.phrs.2006.11.001

5. Kandel E, Schwartz J, Jessell T. Principles of neural science. New York: Elsevier; 1991.

6. Kajantieand E, Phillips DI. The effects of sex and hormonal status on the physiological response to acute psychosocial stress. Psychoneuroendocrinol 2006;31:151-78.

7. National Research Council. Women's health research: Progress, pitfalls, and promise. 4 methodologic issues in women's health research. Washington, DC: The National Academies Press; 2010.

8. Oertelt-Prigione S, Regitz-Zagrosek V. Gender aspects in cardiovascular pharmacology. J Cardiovasc Transl Res 2009;2(3):258-66. http://dx.doi.org/10.1007/s12265-009-9114-9 and develop this component of European social policies. With regard to the current strategy, the EP highlights certain weaknesses, i.e. its non-systematic approach to long-term health effects. The EP emphasizes that women report a higher level of workrelated health problems than men, irrespective of the type of work. Hence measures of health and safety surely need a gender-biased approach. Gender mainstreaming should be implemented across the policies in order to better reflect the specific risks faced by female workers. This note emphasizes that men and women are affected to differing degrees by occupational hazards, be these psychosocial or physical. For this reason, it urges the Member States to take account, in their national strategies, of the gender issue. Of note the EP recommends that the economic effects of the crisis and the severe economic downturn in some Member States should not serve as a pretext for the defective application of legislation on health and safety at work, or undermine occupational risk prevention policies as workers safety and gender-associated safety should be at the first place in a State Agenda. In this context, scientific public or private research institutions should represent the first to pay attention to the safety of their workers, and "gender attention" represents nowadays a masterpiece of this duty.

\section{Conflict of interest statement}

There are no potential conflicts of interest or any financial or personal relationships with other people or organizations that could inappropriately bias conduct and findings of this study.

Received on 7 May 2012.

Accepted on 10 July 2012.

9. Ingelsson E, Pencina MJ, Tofler GH, et al. Multimarker approach to evaluate the incidence of the metabolic syndrome and longitudinal changes in metabolic risk factors. The Framingham Offspring Study. Circulation 2007;116(9):984-92. http://dx.doi.org/10.1161/CIRCULATIONAHA.107.708537

10. Mølstad P. Coronary heart disease in women: less extensive disease and improved long-term survival compared to men. Scandinavian Cardiovascular Journal 2009;43(1):10-6. http://dx.doi.org/10.1080/14017430802455833

11. Kannel WB. The Framingham Study: historical insight on the impact of cardiovascular risk factors in men versus women. Journal of Gender-Specific Medicine 2002;(5)2:27-37.

12. Legato MJ, Gelzer A, Goland R, Ebner SA, Rajan S, Villagra V, Kosowski M. Gender-specific care of the patient with diabetes: review and recommendations. Gend Med 2006;3(2):131-58. http://dx.doi.org/10.1016/S1550-8579(06)80202-0

13. Gruber CJ, Tschugguel W, Schneeberger C, Huber JC. Production and actions of estrogens. $N$ Engl J Med 2002;346(5):340-52. Review. http://dx.doi.org/10.1056/NEJMra000471

14. Vitale C, Mendelsohn ME, Rosano GM. Gender differences in the cardiovascular effect of sex hormones. Nat Rev Cardiol 2009;6(8):532-42. http://dx.doi.org/10.1038/nrcardio.2009.105

15. Franconi F, Carru C, Malorni W, Vella S, Mercuro G. The effect of sex/gender on cardiovascular pharmacology. Curr Pharm Des 2011;17(11):1095-107. 
16. Straface E, Lista P, Gambardella L, Franconi F, Malorni W. Gender-specific features of plasmatic and circulating cell alterations as risk factors in cardiovascular disease. Fundam Clin Pharmacol 2010;24(6):665-74. http://dx.doi.org/10.1111/j.1472-8206.2010.00860.x

17. Pierdominici M, Ortona E, Franconi F, Caprio M, Straface E, Malorni W. Gender specific aspects of cell death in the cardiovascular system. Curr PharDes 2011;17(11):1046-55. Review.

18. Jarvie JL, Foody JM. Recognizing and improving health care disparities in the prevention of cardiovascular disease in women. Curr Cardiol Rep 2010;12(6):488-96. http://dx.doi.org/10.1007/s11886-010-0135-4

19. Straface E, Gambardella L, Mattatelli A, Canali E, Boccalini F, Agati L, Malorni W. The red blood cell as a gender-associated biomarker in metabolic syndrome: a pilot study. Int $J$ Cell Biol 2011;2011:204157. http://dx.doi.org/10.1155/2011/204157

20. Franconi F, Seghieri G, Canu S, Straface E, Campesi I, Malorni W. Are the available experimental models of type 2 diabetes appropriate for a gender perspective? Pharmacol Res 2008;57(1):6-18. Review. http://dx.doi.org/10.1016/j.phrs.2007.11.007

21. Patnaik JL, Byers T, DiGuiseppi C, Dabelea D, Denberg TD. Cardiovascular disease competes with breast cancer as the leading cause of death for older females diagnosed with breast cancer: a retrospective cohort study. Breast Cancer Research 2011;13:R64. http://dx.doi.org/10.1186/bcr2901

22. McCreary DR, Gray RE, Grace SL. Gender differences in cancer mortality risk perceptions and screening behaviors among adults 40-60 years of age. Inte Men's Health 2006;5(1):53-64. http://dx.doi.org/10.3149/jmh.0501.53

23. Reuben SH for The President's Cancer Panel. 2008-2009 Annual Report in President's Cancer Panel. Reducing environmental cancer risk. What we can do now? Bethesda, MD: US department of health and human services, National Institutes of Health, National Cancer Institute; 2010.

24. Paggi MG, Vona R, Abbruzzese C, Malorni W. Gender-related disparities in non-small cell lung cancer. Cancer Lett 2010;1;298(1):1-8. Review. http://dx.doi.org/10.1016/j.canlet.2010.08.009
25. Ruggieri A, Barbati C, Malorni W. Cellular and molecular mechanisms involved in hepatocellular carcinoma gender disparity. Int J Cancer 2010;1;127(3):499-504. Review. http://dx.doi.org/10.1002/ijc.25298

26. European Commission. Radiation protection 125. Low dose ionizing radiation and cancer risk. Proceedings of a scientific seminar held in Luxemburg on 9 November 2000. Luxembourg: Office For Official Publications of the European Communities; 2001.

27. Fucic A, Gamulin M. Interaction between ionizing radiation and estrogen: what we are missing? Med Hypotheses 2011; 77(6):966-9. http://dx.doi.org/10.1016/j.mehy.2011.08.021

28. Rahbari R, Zhang L, Kebebew E. Thyroid cancer gender disparity. Future Oncol 2010;6(11):1771-9. Review. http://dx.doi.org/10.2217/fon.10.127

29. Tronko M, Bogdanova T, Voskoboynyk L, Zurnadzhy L, Shpak V, Gulak L. Radiation induced thyroid cancer: fundamental and applied aspects. Exp Oncol 2010;32(3):200-4.

30. Völzke H, Werner A, Wallaschofski H, Friedrich N, Robinson DM, Kindler S, Kraft M, John U, Hoffmann W. Occupational exposure to ionizing radiation is associated with autoimmune thyroid disease. J Clin Endocrinol Metab 2005;90(8):4587-92. http://dx.doi.org/10.1210/jc.2005-0286

31. National Institute for Occupational Safety and Health Stress at work. US Publication Number 99-101. Cincinnati, OH: NIOSH; 1999.

32. Thomas W, Colligan MSW, and Higgins M. Workplace stress. Journal of Workplace Behavioral Health 2006;21(2):89-97. http://dx.doi.org/10.1300/J490v21n02_07

33. Eng A, 't Mannetje A, McLean D, Ellison-Loschmann L, Cheng S, Pearce N. Gender differences in occupational exposure patterns. Occup Environ Med 2011;68(12):888-94. http://dx.doi.org/10.1136/oem.2010.064097

34. Paolantonio G. Valutare i rischi sul lavoro in un'ottica di genere. Inserto di ISL-Igiene e Sicurezza del lavoro n.10/2010.

35. Sorrentino E, Giammarioli AM, Brandani M, Siracusano A, Malorni W. La sicurezza e la valutazione del rischio sui luoghi di lavoro: una prospettiva di genere. Not Ist Super Sanità 2010;24(4):3-9. 